\title{
Morphometric Evaluation of the Hypothalamic-Ovarian Axis of the Ketonuric, Diabetic Chinese Hamster: Relationship to the Reproductive Cycle
}

\author{
D. R. Garris ${ }^{1}$, C. Smith ${ }^{1}$, D. Davis ${ }^{1}$, A. R. Diani ${ }^{2}$ and G. C. Gerritsen ${ }^{2}$ \\ 'Department of Anatomy, East Carolina University School of Medicine, Greenville, North Carolina and \\ ${ }^{2}$ The Upjohn Company, Diabetes and Athersclerosis Unit, Kalamazoo, Michigan, USA
}

\begin{abstract}
Summary. The relationship between diabetes and the morphological alterations which occur in hypothalamic and ovarian tissue was examined in the long-term, ketonuric-diabetic Chinese hamster. Matched diabetic and non-diabetic control hamsters were inspected daily for changes in the reproductive cycle by vaginal lavage. On dioestrus, animals were perfused, the hypothalamus and ovaries collected, prepared for microscopy and morphometrically analyzed. The nuclei in the medial basal hypothalamus of diabetic hamsters exhibited a decreased area $(p<0.01)$ and neuronal population $(p<0.05-0.01)$ compared with controls. The ovaries of the diabetic animals had a reduced follicular population $(p \leqslant 0.05)$ and an increased atresia
\end{abstract}

rate $(p \leqslant 0.05)$ compared with controls. In addition, all diabetic hamsters were acyclic. In diabetic animals, the corpora luteal cells contained a reduced lipid content $(p \leqslant 0.001)$ which was possibly functionally related to a significant decline in serum progesterone levels $(p \leqslant 0.01)$. Based on these results it is suggested that the hypothalamic-ovarian axis is both morphologically and functionally impaired in the diabetic hamster.

Key words: Hypothalamus, ovary, Chinese hamster, follicle cells, corpora lutea, progesterone, diabetes, reproductive cycle, morphometry.
Experimentally induced destruction of the nuclei in the medial-basal hypothalamus leads to obesity, hyperphagia, hyperinsulinaemia and autonomic neuropathy similar to that associated with diabetes [1-4]. In particular, the ventromedial and arcuate nuclei are also recognized to be involved in regulating the hypothalamic-pituitaryovarian axis in several species $[5,6]$, including the hamster $[7,8]$. These nuclei respond physiologically to direct infusions of glucose [9] and insulin [10, 11] and also contain neurons which concentrate ovarian steroid hormones [6]. An association between reproductive acyclicity and hypothalamic neuropathy, especially in the ventromedial hypothalamic nucleus [12], suggested that the diabetes-associated alterations in hypothalamic regions known to be involved in both ovarian and pancreatic endocrine feedback systems, may be causally related. The following study was undertaken in order to determine: (1) if changes in hypothalamic nuclear area, neuron number or cell density were associated with reproductive dysfunction and (2) the effects of diabetes on ovarian structure and function in the genetically diabetic Chinese hamster.

\section{Materials and Methods}

Adult female genetically diabetic Chinese hamsters from the Upjohn Company colony were housed individually under controlled photoperiod ( $14 \mathrm{~h} \mathrm{light/day)} \mathrm{and} \mathrm{environmental} \mathrm{conditions}\left(23^{\circ} \mathrm{C}\right)$. Each ketonuric diabetic hamster was matched with a non-diabetic control for age, sex and body weight ( $27-45 \mathrm{~g}$ ). Purina Mouse Breeder chow and water were available ad libitum. The reproductive cycle was assessed by daily vaginal lavage, with the presence of a mucous plug used to denote estrus. All diabetic animals exhibited elevated urine glucose levels $(+4$, Ketodiastix $)$ for at least 420 days before the onset of the experiments and elevated urine ketone levels for 140-300 days. The animals were observed for changes in their reproductive cycle, urine glucose and ketone levels for at least 3 weeks before sacrifice.

On the day of dioestrus, a $1.0 \mathrm{ml}$ blood sample was collected by intracardiac puncture for analysis of glucose and ovarian steroid hormone levels in all animals. Blood samples were allowed to clot, centrifuged and the serum stored at $-20^{\circ} \mathrm{C}$ until assayed. Serum glucose levels were analyzed using an autoanalyzer and serum progesterone and oestradiol levels were estimated by radioimmunoassay as described previously [13]. All samples for steroid analysis were run in duplicate in single assays. Progesterone assay sensitivity ranged between 5 and $500 \mathrm{pg}$ with an intra-assay variability of $\leqslant 8 \%$. The intra-assay variability for oestradiol was $\leqslant 5 \%$, with a lower sensitivity limit of $10 \mathrm{pg}$. All values were corrected for procedural loss and recovery.

Following blood collection, the hamsters were anaesthetized with an IP injection of nembutal $(0.02 \mathrm{ml})$ and perfused via the aorta (gravity 
Table 1 . Differences in the area, absolute cell number and cell density of various hypothalamic nuclei from matched control and ketonuric-diabetic Chinese hamsters

\begin{tabular}{|c|c|c|c|c|c|c|c|c|c|c|}
\hline Parameter & Group & \multicolumn{9}{|c|}{ Hypothalamic nuclei } \\
\hline $\begin{array}{l}\text { Area of } \\
\text { nucleus }\left(\mathrm{mm}^{2}\right)^{\mathrm{c}}\end{array}$ & $\begin{array}{l}\text { Control } \\
(n=6)\end{array}$ & $\begin{array}{r}155.6 \\
\pm 12.8\end{array}$ & $\begin{array}{c}1431.6 \\
\pm 134.9^{\mathrm{a}}\end{array}$ & $\begin{array}{c}707.2 \\
\pm 69.0^{\mathrm{b}}\end{array}$ & $\begin{array}{r}352.1 \\
\pm 27.0\end{array}$ & $\begin{array}{c}857.8 \\
\pm 68.4^{b}\end{array}$ & $\begin{array}{l}1066.5 \\
\pm 82.7\end{array}$ & $\begin{array}{c}325.5 \\
\pm 34.7^{\mathrm{b}}\end{array}$ & $\begin{array}{r}1709.3 \\
\pm 40.2\end{array}$ & $\begin{array}{r}647.5 \\
\pm 157.5\end{array}$ \\
\hline \multirow[t]{2}{*}{$\begin{array}{l}\text { Absolute } \\
\text { cell number }\end{array}$} & $\begin{array}{l}\text { Control } \\
(n=6)\end{array}$ & $\begin{array}{r}67.8 \\
\pm 13.0\end{array}$ & $\begin{array}{r}539.8 \\
\pm 22.3\end{array}$ & $\begin{array}{r}419.8 \\
\pm 44.2\end{array}$ & $\begin{array}{r}315.7 \\
\pm 36.3\end{array}$ & $\begin{array}{c}406.3 \\
\pm 68.6^{\mathrm{a}}\end{array}$ & $\begin{array}{c}605.8 \\
\pm 35.7^{\mathrm{b}}\end{array}$ & $\begin{array}{r}167.3 \\
\pm 29.3\end{array}$ & $\begin{array}{r}644.3 \\
\pm 80.6\end{array}$ & $\begin{array}{r}575.0 \\
\pm 36.0\end{array}$ \\
\hline & $\begin{array}{l}\text { Diabetic } \\
(n=6)\end{array}$ & $\begin{array}{r}60.0 \\
\pm 5.7\end{array}$ & $\begin{array}{r}499.2 \\
\pm 26.4\end{array}$ & $\begin{array}{r}368.0 \\
\pm 43.7\end{array}$ & $\begin{array}{r}340.7 \\
\pm 18.7\end{array}$ & $\begin{array}{r}328.0 \\
\pm 25.0\end{array}$ & $\begin{array}{r}498.0 \\
\pm 58.1\end{array}$ & $\begin{array}{r}166.4 \\
\pm 14.2\end{array}$ & $\begin{array}{r}744.3 \\
\pm 67.0\end{array}$ & $\begin{array}{r}411.6 \\
\pm 19.6\end{array}$ \\
\hline $\begin{array}{l}\text { Cell density } \\
\left.\text { (neurons } / \mathrm{mm}^{2}\right)^{\mathrm{d}}\end{array}$ & $\begin{array}{l}\text { Control } \\
(n=6)\end{array}$ & $\begin{array}{r}2235.0 \\
\pm 538.9\end{array}$ & $\begin{array}{r}1931.0 \\
\pm 228.9\end{array}$ & $\begin{array}{r}2519.7 \\
\pm 632.9\end{array}$ & $\begin{array}{r}4329.3 \\
\pm 338.7\end{array}$ & $\begin{array}{r}2361.5 \\
\pm 421.4\end{array}$ & $\begin{array}{c}2856.5 \\
\pm 241.9^{\mathrm{a}}\end{array}$ & $\begin{array}{r}3629.0 \\
\pm 432.4\end{array}$ & $\begin{array}{r}1840.5 \\
\pm 204.9\end{array}$ & $\begin{array}{c}4554.0 \\
\pm 835.5^{\mathrm{a}}\end{array}$ \\
\hline
\end{tabular}

Results are expressed as mean \pm SEM for all hypothalamic nuclei.

${ }^{\mathrm{a}} p<0.05 ;{ }^{\mathrm{b}} p \leqslant 0.01$

c Measurements made at magnification of $\times 70 ;{ }^{d}$ Values corrected for magnification

Table 2. Comparison of corpora lutea area, number, and lipid content in non-diabetic and diabetic Chinese hamsters

\begin{tabular}{llll}
\hline Group & $\begin{array}{l}\text { Number of } \\
\text { corpora lutea } \\
\text { per ovary }\end{array}$ & $\begin{array}{l}\text { Total } \\
\text { corpora luteal } \\
\text { area }\left(\times 100 \mathrm{~mm}^{2}\right)\end{array}$ & $\begin{array}{l}\text { Lipid/cell } \\
\text { area }(\%)\end{array}$ \\
\hline $\begin{array}{l}\text { Control } \\
(n=6)\end{array}$ & $0.6 \pm 0.4$ & $0.36 \pm 0.08$ & 3.2 \\
$\begin{array}{l}\text { Diabetic } \\
(n=6)\end{array}$ & $1.07 \pm 0.7$ & $0.65 \pm 0.23^{\mathrm{a}}$ & $0.5^{\mathrm{b}}$ \\
\hline
\end{tabular}

All values are expressed as mean \pm SEM. ${ }^{a} p<0.05 ;{ }^{b} p<0.001$

feed system) with $15 \mathrm{ml}$ of physiological saline followed by $75 \mathrm{ml}$ of cold $2.5 \%$ gluteraldehyde in $0.075 \mathrm{~mol} / 1$ cacodylate buffer (pH 7.3). After perfusion, the brain and ovaries were removed for processing. Pieces of the hypothalamus were embedded in paraffin using conventional techniques. Serial sections ( $8 \mu$ thickness) were cut and stained with cresyl-violet for light microscopic analysis. Ovaries were embedded in plastic for transmission electron microscopy. Thick sections $1 \mu$ ) were stained with toluidine blue for light microscopic analysis and thin sections $(75 \mathrm{mu})$ used for electron microscopic analysis.

Brain sections were systematically scanned from rostral to caudal limits and the mid-point of each hypothalamic nucleus localized. In this manner, all nuclear regions were compared for neuronal differences between matched diabetic and control groups. The mid-point of each hypothalamic nucleus was photographed and enlarged $(x 70)$ for analysis. The boundaries of each nucleus were identified and its area determined using a light fibre optic coupler and 9874 A digitizer connected to a Hewlett-Packard $9845 \mathrm{~B}$ computer. The absolute number of neurons at the mid-point of each nucleus was then determined by counting each cell which possessed a distinct nucleolus. The density of neurons/unit area of each nucleus was thus calculated and the results expressed as neurons $/ \mathrm{mm}^{2}$ area of nucleus.

The analysis of ovarian tissue was performed in a similar manner as used for hypothalamic determinations. Three cross-sections were selected from the middle region of each ovary, photographed and enlarged for analysis. The area of each ovarian cross-section was computed using the digitizer. The population of primary $(\leqslant 0.02 \mathrm{~mm}$ diameter), secondary (0.02-0.4 mm diameter), tertiary ( $\geqslant 0.5 \mathrm{~mm}$ diameter) and atretic (collapsed zona pellucida) follicles was collected from each photograph (Fig. 1). The area and number of corpora lutea were collected in a similar manner. By electron microscopic analysis, luteal cell size was determined from enlarged micrographs. The percentage of luteal cell area populated by lipid droplets was analyzed by measuring the area of each complete luteal cell and the total area occupied by lipid using the computer and digitizer system. All values were grouped as either diabetic or control and expressed as mean \pm SEM. Intergroup differences were calculated using the Student's t-test, with $p \leqslant 0.05$ considered as significant.

\section{Results}

No significant differences were observed in body, brain or ovarian weights between control and diabetic groups. All control hamsters exhibited a normal, 4-day oestrous cycle, while all the diabetic animals were acyclic. Both urine glucose and ketone levels were elevated in diabetic hamsters compared with the matched controls and serum glucose levels were significantly elevated in the diabetic group $(25.96 \pm 1.69$ versus $6.88 \pm 0.64 \mathrm{mmol} / 1$ for control animals; $p<0.001$ ).

\section{Hypothalamic Analysis}

Analysis of nuclear area, absolute cell numbers and neuronal cell density in various hypothalamic nuclei is summarized in Table 1. Significant differences were observed in either the nuclear area or cell number between control and diabetic hamsters in the anterior, paraventricular, ventromedial, dorsomedial, arcuate and premammillary nuclei. The depression in these parameters in the diabetic hamsters was most pronounced in the medial basal hypothalamus, which consists primarily of the ventromedial, dorsomedial and arcuate nuclei. However, 
only the dorsomedial and premammillary nuclei exhibited significant reductions in their cell density measurements (Table 1). The reduced area of the other nuclei, in association with a comparable or lowered neuron population, accounted for the similar cell density measurements found between groups (Table 1).

\section{Ovarian Analysis}

Definite differences in follicular populations were observed between control and diabetic hamster ovaries (Fig. 1). No differences were calculated for the absolute number of primary or tertiary follicles for either group. However, there was a significant reduction in the number of secondary follicles in the diabetic group as well as a significant increase in the atretic follicle population in this group. In contrast, no differences were observed in the number of corpora lutea per ovary between groups (Table 2), although the area of each corpus luteum was increased in the diabetic animals. However, the lowered serum progesterone levels in the diabetic hamsters indicated that their corpora lutea were not totally functional (Fig. 2). No differences were observed in serum oestradiol levels between groups (Fig. 2).

In order to evaluate the functional disability of the diabetic hamster corpora lutea, the amount of lipid stores in the luteal cells was determined for group comparisons. From electron micrographs, is was obvious that the lipid content of luteal cells in the diabetic animals was greatly reduced compared with controls (Fig.3). This observation was supported quantitatively by calculating the percentage of cell area occupied by lipid in luteal cells from both groups. The results indicate that the luteal cells of diabetic animals contain approximately one-sixth of the lipid stores available for steroidogenesis in the control group (Table 2).

\section{Discussion}

The present report is the first morphometric evaluation of the hypothalamic nuclei in the Chinese hamster and the associated alterations in area, neuronal population and cell density which occur in the long term, ketonuric diabetic state. Interestingly, the major changes were primarily localized to nuclei which have recognized relationships to pancreatic [10] and reproductive [6] function. In particular, the ventromedial and arcuate nuclei are known to be involved in the regulation of pituitary gonadotrophin release [6], as well as to possess insulin sensitive cells $[9,10,14]$. Alterations in these hypothalamic nuclei may account, in part, for the reproductive dysfunction observed in the diabetic animals in the present studies. In addition, since the ventromedial nucleus is reportedly sensitive to glucose and insulin infusions $[9$, 10] as well as to circulating ovarian steroid hormone levels $[5,6]$, this region may serve as an integrator of multiple feedback pathways in both the pancreatic and repro-

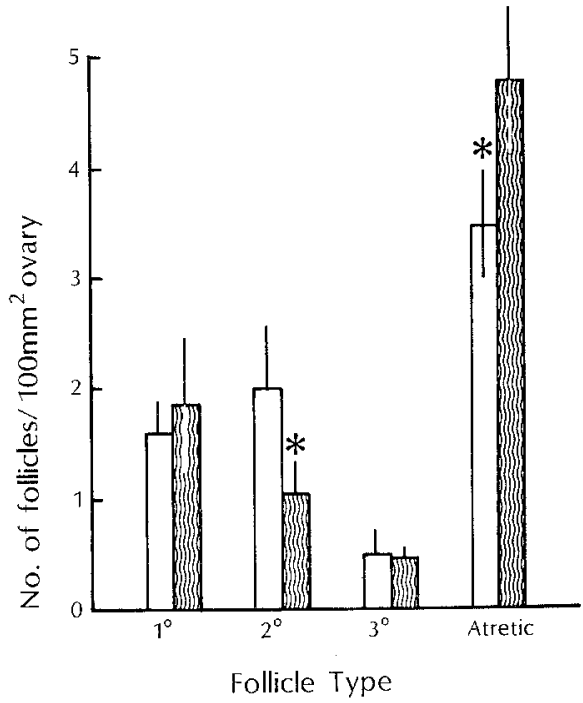

Fig. 1. Comparison of the number of primary $\left(1^{\circ}\right)$, secondary, $\left(2^{\circ}\right)$, tertiary $\left(3^{\circ}\right)$ and atretic follicles in a $100 \mathrm{~mm}^{2}$ area of control $\square$ and diabetic (1010) ovaries. All values are expressed as the mean \pm SEM for six matched pairs. $* p \leqslant 0.005$ between groups
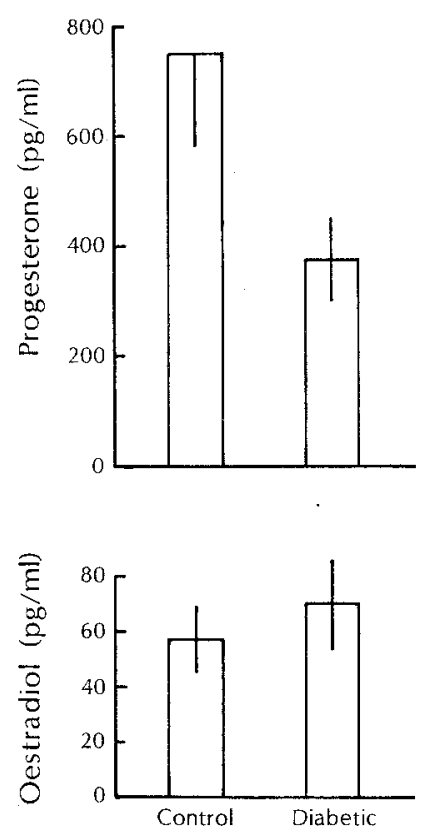

Fig. 2. Serum progesterone and oestradiol levels in control and diabetic Chinese hamsters in dioestrus. All values are expressed as mean \pm SEM for six matched pairs. Serum progesterone levels were significantly lower in diabetic compared with control hamsters $(p \leqslant 0.01)$. No differences were observed in serum oestradiol levels between groups

ductive endocrine systems. Since the present study utilized only long term diabetic hamsters, the temporal relationship between the onset of hypothalamic neuropathy and ovarian dysfunction was not evaluated. However, the consistent observation that diabetic animals exhibiting medial-basal hypothalamic abnormalities were also reproductively quiescent, suggests that the hypothalamic-ovarian axis is defective in the diabetic animal.

Morphological and quantitative evaluation of the diabetic hamster ovaries indicated that a reduced num- 


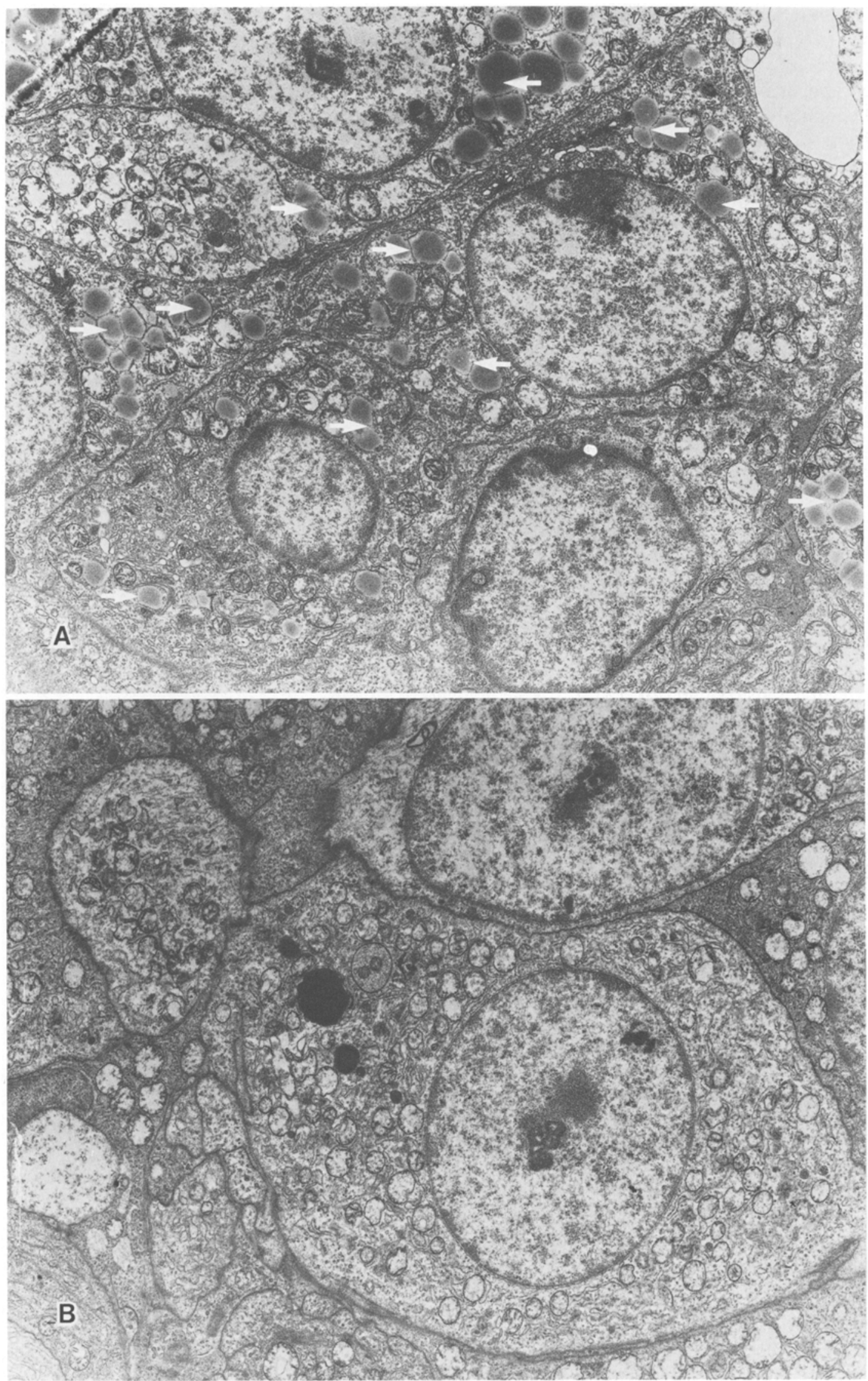

Fig. 3 A and B. Luteal cells from control (A) and diabetic (B) Chinese hamsters comparing the amount of lipid stores. Lipid droplets (Arrows) were greatly reduced in diabetic hamsters. $(\times 9000)$ 
ber of primary follicles were recruited into the secondary population compared with controls. This observation was consistent with the fact that the number of atretic follicles in the ovaries of diabetics was greater than in matched control hamsters. Functionally, serum oestradiol levels were consistent between groups, suggesting that whatever follicles were recruited for development remained viable. The failure of the diabetic animals to exhibit vaginal cyclicity, however, indicated that ovulation did not occur. No evidence of ovulation sites was ever observed in the ovaries examined from diabetic animals.

The luteal tissue in the diabetic hamster was not maximally functional as indicated by the significantly lower serum progesterone levels in this group compared to control hamsters. The lower serum steroid levels were explained by the observation that the luteal cell lipid pool in the diabetic animals was greatly reduced with respect to control values. The lack of insulin in the diabetic animals [15] probably reduced the amount of glucose entering the luteal tissue for conversion to lipid stores. The lack of lipid, in turn, would limit the steroidogenic capabilities of the corpora lutea as indicated by the lowered serum progesterone levels.

Several studies have indicated that lesions of the medial basal hypothalamus in rodents results in reproductive problems similar to those observed in the present study $[7,8,10,16-18]$. This is the first report to document the potential causal relationships between diabetes, hypothalamic changes and reproductive problems in the Chinese hamster. Reproductive problems in diabetic patients are well recognized $[19,20]$, however, the underlying cause or site of the problem is often difficult to determine. The genetically diabetic hamster model in these studies affords an excellent opportunity in which to study the temporal and causal relationships between hypothalamic neuropathy and reproductive dysfunction. Previous studies indicated that the hypothalamic neurons which remained in the ventromedial nuclei of chronically diabetic hamsters were viable, based on morphological criteria [12]. It remains to be determined if the hypothalamic neurons in this model possess insulin or glucose receptors and if receptor population shifts occur as diabetes progresses.

In summary, both hypothalamic as well as ovarian changes were morphometrically documented in the long-term, ketonuric-diabetic Chinese hamster. These data suggest that a causal relationship exists between diabetes and several endocrine and autonomic irregularities reported in this species. The interesting localization of hypothalamic neuropathy in the medial basal area and the known regulatory effects of this region on reproductive function indicate that the diabetes-induced changes may result from a block in a neuroendocrine feedback system involving both the pancreas and ovary.

Acknowledgements. Supported in part by The Upjohn Company and NIH Grant AM-21933-02.

\section{References}

1. Hetherington A, Ranson SW (1940) Hypothalamic lesions and adiposity in the rat. Anat Rec 78:149-172

2. Hales CN, Kennedy GC (1964) Plasma glucose, non-esterified fatty acid and insulin concentrations in hypothalamic-hyperphagic rats. Biochem J 90: 620-624

3. Frohman LA, Bernardis LL (1968) Growth hormone and insulin levels in weanling rats with ventromedial hypothalamic lesions. Endocrinology 82:1125-1132

4. Sclafani A (1981) The role of hyperinsulinaemia and the vagus nerve in hypothalamic hyperphagia reexamined. Diabetologia 20: 402-410

5. Barraclough CA (1973) Sex steroid regulation of reproductive neuroendocrine processes. In: Greep RO (ed) Handbook of physiology, Sect 7, vol 2, pt 1. American Physiological Society, Washington, DC, pp 29-56

6. Garris DR, Billiar RB, Takaoka Y, White RJ, Little B (1981) In situ oestradiol and progestin (R 5020) localization in the vascularly separated and isolated hypothalamus of the rhesus monkey. Neuroendocrinology 32: 202-208

7. Lamperti A, Blaha G (1976) The effects of neonatally-administered monosodium glutamate on the reproductive system of adult hamsters. Biol Reprod. 14: 362-369

8. Komeda K, Yokote M, Oki Y (1980) Diabetic syndrome in the Chinese hamster induced with monosodium glutamate. Experientia $36: 232-234$

9. Chhina GS, Anand BK, Singh B, Rao SP(1971) Effect of glucose on hypothalamic feeding centers in deafferented animals. Am J Physiol 221:662-670

10. Woods SC, Smith PH, Porte D Jr(1981) The role of the nervous system in metabolic regulation and its effects on diabetes and obesity. In: Brownlee M (ed) Handbook of Diabetes Mellitus. Garland STPM Press, New York, pp 209-271

11. Storlien LH, Bellingham WP, Martin GM (1975) Localization of CNS glucoregulatory insulin receptors within the ventromedial hypothalamus. Brain Res 96: 156-160

12. Garris DR, Diani AR, Smith C, Gerritsen GC (1982) Depopulation of the ventromedial hypothalamic nucleus in the diabetic, Chinese hamster. Acta Neuropathol 56:63-66

13. Garris DR, Whitehead DS (1981) Uterine blood flow and timing of blastocyst implantation in the guinea pig. Am J Physiol 241: E142-145

14. Oomura $Y$, Kita $H$ (1981) Insulin acting as a modulator of feeding through the hypothalamus. Diabetologia 20: 290-298

15. Gerritsen GC, Dulin WE (1967) Characterization of diabetes in the Chinese hamster. Diabetologia 3: 74-84

16. Meijs-Roelofs Moll J (1972) Differential effects of anterior and middle hypothalamic lesions on vaginal opening and cyclicity. Neuroendocrinology 9:297-303

17. Redding TW, Schally AV, Arimura A, Wakabayashi I (1971) Effect of monosodium glutamate on some endocrine functions. Neuroendocrinology $8: 245-255$

18. Trentini GP, Botticelli A, Botticelli CS (1974) Effect of monosodium glutamate on the endocrine glands and on reproductive function of the rat. Fert Steril $25: 478-483$

19. Schreiner WE (1976) The ovary. In: Labhart A (ed) Clinical endocrinology, Springer-Verlag, New York, pp 509-665

20. Williams RH, Porte D Jr (1974) The Pancreas. In: Williams RH (ed) Textbook of Endocrinology. Saunders, Philadelphia, pp 502-626

Received: 26 November 1981

and in final form: 20 May 1982

Dr. David R. Garris

Department of Anatomy

East Carolina University School of Medicine

Greenville, North Carolina 27834, USA 